'Directive Principles and the Expressive Accommodation of Ideological Dissenters' (2018) 16(2) International Journal of Constitutional Law 389

\title{
Directive Principles and the Expressive Accommodation of Ideological Dissenters
}

\section{Tarunabh Khaitan*}

This article argues, using India as a case study, that constitutional directives can be a useful tool for the expressive accommodation of ideological dissenters who would otherwise lose out in constitutional negotiations in deeply divided societies. Under certain conditions, these directives can be useful in getting populist illiberal groups to sign up to a (broadly) liberal constitution. Framers of the Indian Constitution successfully accommodated some such groups using constitutional directives, and tempered this accommodation through strategies of containment and constitutional incrementalism. Such calibrated accommodation can give dissenting groups enough (and genuine) hope of future political victories without going so far that their opponents in turn leave the constitutional negotiation table. By focusing on the accommodational needs of ideological dissenters, this article adds to existing literature on constitutional consensus-building techniques, which has largely focused on political insurance for ethnocultural minorities. It also highlights a key function of constitutional directives, which have hitherto been considered at best to be interpretive aids in constitutional adjudication, and at worst as constitutional dead weight.

\section{Introduction}

Constitution-making in deeply divided societies - where the transaction cost of securing consensus over key decisions is extremely high - poses a dilemma. On the one hand, the usual aspiration to create an enduring constitution demands a broad consensus over its contents. On the other hand, its very potential endurance signals to groups that believe they have lost out in the constitutional negotiation that their loss might be permanent, encouraging intransigence. The literature on accommodation of intransigent groups in such societies has largely focused on ethnocultural minority groups that fear being permanently locked out of power under a majoritarian democratic constitution. This literature treats constitution-making as an elite-driven process of interest-bargaining, where the minority group seeks political insurance in form of power-sharing arrangements, decisional vetoes, or legal disabilities on majoritarian decision-making.

Ethnocultural minorities are not, however, the only groups threatened by liberal democratic constitutions. While liberal constitutions tend to provide the widest latitude to future governments of different ideological make-ups, certain ideological groupsespecially those whose political agendas sit uncomfortably with the liberal commitment to individual human rights - also have reasons to withhold consent. These groups typically care about religious or economic ideologies (religious establishment, state socialism, etc.) which often concern the very identity of the state itself. The distinction between ideological and ethnocultural groups is, admittedly, not entirely neat, but it is nonetheless a useful heuristic. In this article, I will show that (i) the accommodational needs of ideological dissenters are different from ethnocultural minorities, and (ii) one of the ways to secure their consent for a broadly liberal democratic constitution while also keeping their ideological opponents on board is the contained and incrementalized 
expressive accommodation of their ideological agenda in the form of constitutional "directive principles."

Directive principles are expressive constitutional directives to the political organs of the state to programmatically secure certain transformative goals. Constitutional texts typically describe them as "not enforceable by any court" but "nevertheless fundamental in the governance of the country." They are called by various names, including directive principles of state policy, directive principles of social policy, fundamental principles of state policy, fundamental objectives, national objectives, or some combination thereof. I will refer to them as directive principles, constitutional directives, or simply directives. ${ }^{2}$ Although the South African Constitution famously rejected directive principles as inadequate for its transformative agenda, they have - alongside preambles — been rather popular with framers seeking to enshrine transformative ideals in their constitutions elsewhere. Despite this, they have largely, and surprisingly, been overlooked by international and comparative constitutional law scholarship.

What little scholarly attention they have received has often been critical. Largely because of their non-justiciable character, they have been characterized at best as provisions with a "mere moral appeal" 3 and "no practical implication," 4 at worst as "design flaws." 5 Their offhand dismissal by scholars - in thrall of a narrow imagination of constitutions as judicially enforced supreme law - is at odds with their persistent popularity with framers of constitutions. If they are so useless, why have over thirty-one constitutions

\footnotetext{
* Associate Professor \& Hackney Fellow, Wadham College, Oxford \& Associate Professor \& Future Fellow, Melbourne Law School. Email: t.khaitan@unimelb.edu.au. I am grateful to all those friends, colleagues, workshop participants, and reviewers who commented on various drafts of this article. Usual disclaimers apply. Special thanks to Ira Chadha-Sridhar for excellent research assistance.

${ }^{1}$ India Const. art 37 . Some scholars find the bar on "enforcement" to be compatible with judicial cognizance of directive principles that falls short of enforcement: Joseph Minattur, The Unenforceable Directives in the Indian Constitution, 1 Supreme Court Cases (SCC) (J.) 17 (1975). Without disputing this doctrinal claim, I will use the terms "enforceability" and "justiciability" interchangeably.

2 The term "directive principles" is not intended to track the familiar debate concerning the distinction between rules and principles: Ronald Dworkin, Taking Rights Seriously: New Impression with a Reply to Critics ch. 2 (2004).

${ }^{3}$ Dejo Olowu, An Integrative Rights-Based Approach to Human Development in Africa 96-98 (2009).

${ }^{4}$ Christophe Jaffrelot, Dr Ambedkar and Untouchability: Analysing and Fighting Caste 112 (2005).

${ }^{5}$ Jeffrey Usman, Non-Justiciable Directive Principles: A Constitutional Design Defect, 15 Mich. St. Int'l L. Rev. 643 (2007). See also Okere, who rues the absence of even a Conseil Constitutionnel type enforcement body for the Nigerian directive principles: B. Obinna Okere, Fundamental Objectives and Directive Principles of State Policy Under the Nigerian Constitution, 32 Int'l \& Comp. L.Q. 214, 221 (1983).
} 
adopted them in some form or the other, ${ }^{6}$ and even amended them subsequently? ${ }^{7}$ When it is not dismissive, existing scholarship has focused mostly on what courts have managed to do with these supposedly non-justiciable constitutional provisions, especially in relation to fundamental rights - briefly, courts have used them as interpretive tools, as a source of unspecified fundamental rights, and as a reason to defer to a law or policy whose constitutionality is under attack. ${ }^{8}$ But if we are to permit some idealism, creativity, and thoughtfulness to the makers of these constitutions, predominantly from the global South, better explanations are likely to be found beyond the legalistic confines of constitutional scholarship dominated by the American experience.

In this article, I will argue, using India as a case study, that constitutional directives can be a useful tool for the contained, incrementalized, and expressive accommodation of ideological dissenters who would otherwise lose out in constitutional negotiations in deeply divided societies. They have an instrumental value at the very moment of constitutional founding, inasmuch as they can secure the buy-in of dissenting groups for the constitutional project, and generate a broad consensus over the document as a whole, without giving in so much to the dissenters' demands that the majority rejects the accommodation. The two consent-seeking strategies that can be seen in the relevant type of Indian directives (that I will label "deeply contested directives") are containment and constitutional incrementalism. These strategies give enough (and genuine) hope of future victories to the dissenting groups to keep them on board, without accommodating them so much that their opponent groups in turn leave the constitutional negotiation table. As one of the most enduring examples of post-colonial constitutions, the contained and incrementalist accommodation of the dissenters in the Indian Constitution might well be key to its remarkable survival.

\footnotetext{
${ }^{6}$ These include the constitutions of: Ireland (1937), India (1950), Qatar (provisional constitution, 1970), Bangladesh (1972), Tanzania (1977), Sri Lanka (1978), Nigeria (1979), Jammu and Kashmir (1984), Nepal (1990), Namibia (1990), Sierra Leone (1991), Zambia (1991), Papua New Guinea (1991), Tibet (constitution of the government in exile, 1991), Ghana (1992), Lesotho (1993), Uganda (1995), Ethiopia (1995), Gambia (1996), Eritrea (1997), Thailand (1997), Sudan (1998), Western Cape (1998), Nigeria (1999), Somaliland (2001), Swaziland (2005), Thailand (2007), Nepal (interim constitution, 2007), Bhutan (2008), South Sudan (2011), and Nepal (2015). This list does not include possibly comparable directives (called "state tasks") in some European jurisdictions like Germany and Austria. See generally Karl-Peter Sommermann, Staatsziele und Staatszielbestimmungen (1997). While Jennings claims that Ireland itself borrowed its directives from Republican Spain: Ivor Jennings, The Approach To Self-Government 19 (1958), Walsh suggests, perhaps more reliably, that the inspiration might have come from provisions (such as article 151) concerning "Economic Life" in the Weimar Constitution: Rachel Walsh, Private Property Rights in the Drafting of the Irish Constitution: A Communitarian Compromise, 33 Dublin U. L.J. 86, 95 (2011). Also excluded from the list are "positive rights" in communist constitutions - such as the right to work under article 40 of the Constitution of the Union of Soviet Socialist Republics 1977 - which were also typically non-justiciable. On environmental.

7 See India Const. arts. 38(2), 39(f), 39A, 43A, 43B, and 48A. See also Amit Sibal, From "Niti" to "Nyaya," We The People: A Symposium on the Constitution of India, After 60 Years, 1950-2010 (Nov. 2010), available at http://www.india-seminar.com/2010/615/615_amit_sibal.htm.

${ }^{8}$ P. K. Tripathi, Directive Principles of State Policy: The Lawyer's Approach to Them Hitherto, Parochial, Injurious and Unconstitutional, 17 SCC (J.) 7 (1954); Upendra Baxi, Directive Principles and the Sociology of Indian Law: A Reply to Dr Jagat Narain, 11 J. Indian 1. Inst. 245 (1969); Jagat Narain, Judicial Law Making and the Place of Directive Principles in Indian Constitution, 27 J. Indian 1. Inst. 198 (1985); Bertus de Villiers, Directive Principles of State Policy and Fundamental Rights: The Indian Experience, 8 s. Afr. J. hum. Rts. 29, 39f (1992); M. P. Singh, The Statics and the Dynamics of the Fundamental Rights and the Directives Principles: A Human Rights Perspective, SCC (J.) 1 (2003); Gautam Bhatia, Directive Principles of State Policy, in the oxford handbook of the Indian Constitution (Sujit Choudhry, Madhav Khosla, \& Pratap Bhanu Mehta eds., 2016).
} 
The inquiry will be conducted by paying close attention to the political speeches and interventions made by representative players in the debates of India's constituent assembly. Two caveats: first, I do not wish, in this article, to get into the potential role that the framers' original intent might have on constitutional interpretation by future generations. All I wish to do is to explain and defend some of the positions adopted by some key drafters. What weight, if any, the original intentions of the framers deserve from us today is a separate question. Second, I am not suggesting that directive principles necessarily played a similar role outside India, or even that all Indian directives played such a role. The Indian example is meant to reveal one (of possibly several) functions they could perform: securing the consent of ideological dissenters. Whether they played a similar role elsewhere is a matter for another study. This study of one of the most enduring post-colonial constitutions brings together the growing scholarly interest in three distinct issues: the longevity of national constitutions, political/non- legal constitutionalism and constitution-making in deeply divided societies.

Section 2 will clarify the nature of ideological groups in deeply divided societies, and distinguish them from ethnocultural minorities. It will hypothesize that these groups are politically optimistic, and therefore seek expressive recognition of their agendas rather than political insurance through constitutionally guaranteed power-sharing. Section 3 will first analyze the nature of directive principles generally and identify their key conceptual features: these directives are constitutional, directive and directional, political, programmatic, transformative, and expressive. Section 4 will provide the historical context of the late 1940s in which India framed its constitution. It will identify the chief characteristics of the largely liberal-democratic-secular draft constitution. Drawing upon the debates in the constituent assembly that finalized the constitution, it will also identify and explain the three main dissenters: groups whose hopes, aspirations, and ideals found little, if any, place in the draft document. These groups can loosely be called socialists, Gandhians, and cultural nationalists. Section 5 will then give an overview account of the directives found in the Indian Constitution, and classify them on the basis of the degree of (dis)agreement that surrounded them. The directives in the first category - mostly concerning basic social guarantees - are the uncontested directives; the second category includes the partially contested directives - primarily requiring distributive justice - whose goals were accepted by almost everyone but the means to secure these goals were seriously contested; and the third category includes the deeply contested directives. Section 6 will discuss the two strategies that qualified the accommodation of the dissenters' agendas: containment and constitutional incrementalism. The three containment tools used by the framers were dilution, instantiation, and qualification. There are reasons to think that the constitutional containment of the radical agendas has played some role in their future political containment too. Constitutional incrementalism was secured by the deferral of the realization of the directives to future politics. The section will also explain that the directives are not just incrementalist in the constitutional sense: at least Ambedkar thought that the duties they impose ought to be realized in a politically incrementalist fashion. These strategies represent a fine balancing act that maintained the overall normative coherence of the draft constitution while providing limited and deferred, but genuine, accommodation to the dissenters, thereby securing a broad consensus over the eventual Constitution of 1950. The concluding Section 7 will briefly discuss the afterlife of the contested directives and suggest that the dissenters' hope of future political realization will be vindicated somewhat, albeit in a contained and incremental manner. 


\section{Securing dissenters' consent}

Constitutional theorists have started paying attention to constitution-making in deeply divided societies relatively recently. ${ }^{9}$ A defining feature of such societies is very high decision costs, which Dixon and Ginsburg describe as "a form of transaction costs" that include "the costs of deliberating, negotiating and finalizing an agreement." 10 Given these high transaction costs in such societies, drawing up a constitution that simultaneously satisfies normative legitimacy constraints (that, in the liberal conception, for example, rest on the centrality of individual freedom) and sociological stability constraints (that require sufficient popular allegiance to a constitution to ensure the survival of a political community) can be extremely hard. ${ }^{11}$ The stability constraint, our primary concern here, requires "self-enforcement" as a feature of successful constitutions, i.e., "those within the constitutional bargain must have a stake in the successful implementation of the document for it to endure. Even though constitutional bargains may have relative winners and losers, they will endure to the extent that parties believe they are better off within the current constitutional bargain than in taking a chance on, and expending resources in, negotiating a new one." 12

Tools that reduce decision costs can be categorized into two distinct sets: one deals with power-sharing and institutional design concerns of ethnocultural minorities; another addresses disagreements over the values, ideology, identity, and policy goals of the putative state. The two are obviously interrelated, for institutional choices (such as whether to devolve state power to villages) often reflect the values of the state. Even so, it is helpful to distinguish institutional and ideological disagreements.

The first set of tools, better-developed in the literature, primarily relates to the institutional arrangements of the future state, and whether each warring tribe can be sufficiently reassured that it will wield adequate power and influence in the state being constituted. Tools that secure political insurance for salient ethnocultural groups include consociation, centripetalism, federalism, and so on. ${ }^{13}$ These institutional structures may include procedures for resolving ideological disputes over values politically after the constitution becomes operational. But they are usually not equipped to deal with such disagreements during the framing of the constitution itself. As long as groups are interested in winning not just ideological battles in the future but also some constitutional endorsement of their positions to begin with, institutional tools will be important but

\footnotetext{
${ }^{9}$ See generally Sujit Choudhry, Constitutional Design for Divided Societies: Integration or Accommodation? (2008).

${ }^{10}$ Rosalind Dixon \& Tom Ginsburg, Deciding Not to Decide: Deferral in Constitutional Design, 9 Int'1 J. Const. 1.636, 642 (2010).

${ }^{11}$ Sujit Choudhry, Citizenship and Federations: Some Preliminary Reflections, in the federal vision 382

383 (Kalupso Nicolaidis \& Robert Howse eds., 2001).

12 Zachary Elkins, tom Ginsburg, \& James Melton, the endurance of national Constitutions 7 (2009).

${ }^{13}$ See generally John McGarry, Brendan O’Leary, \& Richard Simeon, Integration or Accommodation?

The Enduring Debate in Conflict Regulation, in Constitutional Design for divided societies: Integration or accommodation? 42 (Sujit Choudhry ed., 2008). Only recently have we seen taxonomical nuance in the political insurance literature: see generally Rosalind Dixon \& Tom Ginsburg, The Forms and Limits of Constitutions as Political Insurance, 15(4) Int'1 J. Const. 1. 988, 989 (2017), who distinguish between political insurance against reduced political power, reduced policy influence, and individual persecution. In this framework, constitutional directives may be seen as providing political insurance with respect to policy influence.
} 
insufficient to address disagreements over values in deeply divided societies.

Thus, the second - underexplored - toolbox relates not so much to institutional powersharing but mostly to the disagreements over the normative values that constitutions (as mission statements) should or should not endorse. Divergent groups are invested not only in their share of power in the future state but also in the moral identity of that state: they worry about what this state will be like, what symbols will represent it, what values it will cherish, and what goals it will pursue. Ideological disagreements concerning the relationship between the state and religion or the economic character of the state (capitalist, socialist, communist) have been especially divisive in many contexts. These ideological demands are not presented as interest- bargaining between social groups. Instead, they claim to speak for the "people" or the "nation" as a whole. Their accommodation isn't, then, a zero-sum game, and they tend to focus on expressive recognition of their ideological agenda rather than a guaranteed share in state power. This is in part because, unlike ethnocultural minorities who are politically pessimistic under winner-takes-all majoritarian decision-making rules, ideological dissentersespecially of a populist orientation - tend to be political optimists under conditions of democracy.

One might think that ideological groups can be accommodated by simply minimizing the ideological commitments that a constitution makes. This is almost impossible in societies where a procedural liberal democratic framework is itself viewed as partisan (usually seen as siding with capitalism and secularism), rather than one that merely provides a level playing field for other ideologies to battle it out. At any rate, very few constitutions can get away with simply constituting an institutional frame- work and ignoring all normative and expressive questions. Even the minimalist US Constitution had to grapple with the morally divisive issue of slave trade, dealt with through a classic deferral tool: freezing the status quo for twenty years and passing the problem on to Congress. ${ }^{14}$ The problem is more acute for constitutions with transformative agendas. How can they secure the consent of dissenting ideological groups? In day-to-day politics, losers' consent is critical for the normal functioning of any democratic polity, especially if rebellion or civil war is to be averted. ${ }^{15}$ This is usually avoided by the promise that political losses (and victories) are transient and reversible. But ideological dissenters may see constitutional defeats as permanent, whereas securing the consent of at least the salient ideological groups for the constitution is essential if the constitutional state is to have any chance of taking off and if the constitution is to become self-enforcing and therefore stable.

By highlighting the distinctive nature of ideological dissenters, using Indian as a case study, this article will address a major gap in the literature on dealing with disagreement in the constitution-making process. It will show that politically optimistic ideological groups mainly seek expressive recognition of their agendas in the constitution. While they would have preferred a wholesale adoption of their ideology by the constitution, failing that, even a limited constitutional recognition of their agenda and a guarantee that the constitution would not stand in the way of the political implementation of these agendas might sometimes be sufficient to get them on board. A constitution has several expressive tools, chief among them are preambles and recitals. But preambular

\footnotetext{
${ }^{14}$ U.S. Const. art.1, § 9.

${ }^{15}$ Christopher Anderson et al., losers' Consent: Elections and democratic legitimacy 6 (2005).
} 
recognition carries with it a salience that might irritate the ideological majority a little too much. Directive principles - a more calibrated expressive tool—were successfully used by the Indian framers instead to secure the consent of ideological dissenters to the liberal draft constitution, without losing the support of the majority in the constituent assembly.

\section{What are Directive Principles?}

Directive principles are expressive constitutional directives primarily addressed to the political organs of the state to programmatically secure certain social, political or economic goals of a "transformative" character. These features are not meant to distinguish directives from rights, at least not sharply. Fundamental rights can also be expressive, programmatic, and transformative. It may well be that the distinction between rights and directives is a matter of degree rather than type. Bearing this caveat in mind, let us examine some of the key features of constitutional directives.

First, directive principles are constitutional. There are no doubt examples of comparable directives contained in legislation, which may or may not have a constitutional character, ${ }^{16}$ but in this article, I am particularly interested in the reasons that framers of big-C constitutional codes have for incorporating directive principles. This feature also distinguishes them from mere moral or political norms, at least in the sense that directives are posited social facts that can be found in constitutional documents. ${ }^{17}$ Given the expressive importance of a big-C Constitution in most jurisdictions that have them, their constitutional status must give directives a certain salience. ${ }^{18}$

Second, these are directives. Through them, framers intend to impose certain duties on the political organs of the state. They are "directive" in two different senses: in the first sense they are directions or imperatives addressed to the legislature. In the second sense, they determine the direction of travel for the future state's policy, although - depending on the level of abstraction in which the directive is specified - this can leave a very broad or relatively little discretion with the future policymaker.

Third, these directives are primarily addressed to the political organs of the state, i.e., the executive and the legislature. ${ }^{19}$ This feature is connected to their supposed nonenforceability by courts. In most constitutions that contain them, their non-justiciability is expressly provided for in the text. In other constitutions, such exclusion may be

\footnotetext{
16 See, e.g., United Kingdom Child Poverty Act (2010).

17 Alon Harel, why law matters 154 (2014). Harel has a broader understanding of what he terms "constitutional directives," and he suggests that they may be found in other social facts too, such as conventions, practices, and institutional history. This may well be true, but here I am interested only in those posited in constitutional documents as directives

${ }^{18} \mathrm{Jeff}$ King, Constitutions as Mission Statements, in social and political foundations of Constitutions 87 (Denis J. Galligan \& Mila Versteeg eds., 2015). See also Harel supra note 17, at 180 ("to the extent that the legislature fails to honour these directives, it is subjected to effective condemnation.").

${ }^{19}$ I do not deny that courts too are/can be political. But, usually, they are political in a differentattenuated—sense.
} 
through implication or convention. ${ }^{20}$ Non-justiciability is a key reason for the controversy surrounding directive principles, and for their rejection in the South African Constitution, which opted instead for justiciable rights. Many courts have found ways to do something with these principles, even when they are prohibited from "enforcing" them. But the key design feature of the directive principles is that they are primarily addressed to the legislature and the executive.

Fourth, they are programmatic rather than being exclusively performative. A performative act is one that may be performed simply by an utterance. For example, saying "I promise to do $\mathrm{x}$ " is (in ordinary circumstances) the same as actually promising to do x. Some legal systems recognize the utterance of "talaaq" as performing the act of divorce. A constitution that declares that "all existing laws of the previous regime shall continue to have the force of law" confers on them legal validity simply by saying so.

Programmatic acts are different, even though they may have a performative dimension. Mere utterance does not secure their realization. There is a time lag between the (performative) adoption of the goal and its realization. Sometimes this gap may be short: a constitution may require Parliament to pass a law outlawing a certain practice, and it may be that Parliament does so in very little time. A program to set up a new administrative machinery might take longer. Social transformation of the sort that directive principles seek is programmatic in a more complicated sense: as we will see while discussing political incrementalism, they typically require sustained, multipronged and multi-stepped effort over a long period of time. As Naziruddin Ahmad put it in the context of the language directive, "You cannot make a language suitable for a modern world by legislative vote." "Use of verbs such as "strive," "direct," "take steps," "make effective provisions for," "endeavor," and "promote" confirm the programmatic character of directive principles.

Fifth, as already seen, directive principles set out a transformative agenda for the state being constituted. "Transformative" constitutionalism is a neologism coined by Karl Klare to describe the South African Constitution:

By transformative constitutionalism, I mean a long-term project of constitutional enactment, interpretation, and enforcement committed ... to transforming a country's political and social institutions and power relationships in a democratic, participatory, and egalitarian direction. Transformative constitutionalism connotes an enterprise inducing large-scale social change through nonviolent political process grounded in law. I have in mind a transformation vast enough to be inadequately captured by the phrase "reform," but something short of or different from "revolution" in any traditional sense of the word. ${ }^{22}$

With Klare, I use the term "transformative constitutionalism" to signify a constitutionally

\footnotetext{
${ }^{20}$ On the status of the Ghanaian and Ethiopian Constitutions which do not have a non-justiciability clause, see Abdi Jibril Ali \& Kwadwo Appiagyei-Atua, Justicieability of Directive Principles of State Policy in Africa: The Experiences of Ethiopia and Ghana, 1 Ethiopian J. hum. rts. 1 (2013).

219 (India) Constituent assembly debates (Cad), Nov. 12, 1949, 1330-1331 (Ahmad).

${ }^{22}$ Karl Klare, Legal Culture and Transformative Constitutionalism, 14 s. Afr. J. hum. Rts. 146, 150 (1998) (emphasis added).
} 
mandated change of a large scale to be brought about using legal-political means (i.e., means that are compliant with the rule of law). My use of the term, however, diverges from Klare's in two respects. First, I use the term "transformative" in a literal and valueneutral sense. For Klare, as the emphasized words in the quote above suggest, transformative constitutionalism must seek what he calls a "postliberal" democratic and egalitarian ideal. But some transformative efforts could and, as we will see in the Indian example, did travel in different directions. While I mostly agree substantively with Klare's democratic and egalitarian ideal, it is unwise to restrict the concept of constitutional transformation to what one might consider "desirable" transformation: that task should be left to qualifying adjectives.

Second, Klare writes in the context of the South African constitution, which expressly rejected non-justiciable directive principles in favor of a more rights-based and judiciaryled transformation. ${ }^{23}$ My use of the term remains agnostic with regard to the constitutional mechanism constructed to seek such transformation, as it does with respect to the direction of the transformation. In fact, Weis claims that at least some of the "rights" guaranteed in the South African Constitution are actually better understood as directive principles. ${ }^{24}$ Furthermore, directive principles have tended to include a broader transformative agenda than social rights: to use Rawlsian terminology, social rights have mostly been restricted to "constitutional essentials" required by his "first principle" of justice, including the right to food, shelter, education, and so on. Directive principles, on the other hand, also tend to include redistributive agendas seeking to reduce income and wealth inequalities, required by the "difference principle" of justice. ${ }^{25}$ As such, I take transformative constitutionalism to mean a constitutional mandate to transform a society, economy, and polity on a large scale through legal-political means.

On this understanding, directive principles clearly qualify as tools in the service of transformative constitutionalism. They are not the only tool, as the South African example demonstrates. They may not even be the best tool for the purpose, although their relative efficacy in securing the constitutionally mandated transformation is not a question this article is concerned with.

Finally, and importantly for our purposes, directives perform an expressive function. A directive's endorsement of an agenda bestows upon it a degree of symbolic constitutional legitimacy. Constitutions are expressive documents generally, and several parts — such as preambles, recitals, and rights - have especial expressive salience. The expressive role of

\footnotetext{
${ }^{23}$ On the debate regarding whether to include such directives, see D. M. Davis, The Case Against the Inclusion of Socio-Economic Demands in a Bill of Rights Except as Directive Principles, 8 s. Afr. J. hum. rts. 475 (1992); Bertus de Villiers, Socio-Economic Rights in a New Constitution: Critical Evaluation of the Recommendations of the South African Law Commission, 3 J. s. Afr. 1. 421 (1992). On other scholars who have focused on the role of courts in exploring transformative constitutionalism, see transformative Constitutionalism: Comparing the apex Courts of Brazil, India and south Africa (Oscar Vilhena, Upendra Baxi, \& Frans Viljoen eds., 2013); Constitutionalism of the global south: the activist tribunals of India, south Africa, and Columbia (Daniel Bonilla Maldonado ed., 2013); Gautam Bhatia, Equal Moral Membership: Naz Foundation and the Refashioning of Equality under a Transformative Constitution, 1 Ind. L. Rev. 115 (2017).

${ }^{24}$ Lael Weis, Constitutional Directive Principles, 37 oxford J. legal stud. 916, 921 (2017).

25 John Rawls, Justice as fairness 47-48 (2001) [rawls, Justice]; John Rawls, political liberalism 228-229 (1993) [hereinafter Rawls, political liberalism].
} 
constitutional directives has been highlighted by scholars relatively recently. ${ }^{26}$ What hasn't been especially noted is that the expressive salience of different parts of a constitution may well be different. Directives are a unique halfway house: constitutionally embedded but with a lower expressive salience than agendas and values endorsed by preambles and fundamental rights. The symbolism of preambles and fundamental rights go to the heart of the character and identity of the state, in a manner that is not necessarily true of mutually contradictory directive principles. This calibrated expressivism makes directives an especially useful tool for recognizing even those agendas that might be against the spirit of the constitution as a whole.

\section{India at its founding: a deeply divided society}

It is sometimes assumed that the founding of India and its early post-independence politics rested on a broad consensus within its governing elite, framed by a liberal, multicultural, democratic, secular, planned-economy vision of Jawaharlal Nehru, India's first prime minister. ${ }^{27}$ While Nehru did embody these ideals, no such consensus actually existed among the ruling elite, which is unsurprising given the almost proverbial scale of India's diversity. Churchill had once remarked that "India is an abstraction ... It is no more a united nation than the Equator." 28 The constituent assembly, even though largely made up of Congress Party members and the rump of the Muslim League that stayed behind after Partition, was ethnoculturally diverse and ideologically a deeply divided body. ${ }^{29}$ This was in part due to the diversity and division within the Congress itself, and because of its policy of accommodating on the party's ticket the candidacy of party outsiders who represented minorities or possessed technical expertise. ${ }^{30}$ It therefore represented most of the influential shades of Indian public opinion. The Indian polity at its founding witnessed deep disagreements - not only in the sense that the dissenters were politically significant but also that the dissent concerned fundamental matters and was strongly felt, strongly enough to potentially get in the way of their accepting the constitution. I use the term "deeply divided society," at least in the context of framing a constitution, as one where several politically significant groups with mutually incompatible, even hostile, agendas consider holding out or walking out of the constitutional negotiation as a feasible option, and whose exercise of that option could seriously undermine the perceived legitimacy of the constitution in the population generally. The transaction cost of agreeing upon a constitution is, therefore, very high.

Our narrative of a divided India framing its constitution starts in the middle: when Dr. Ambedkar - a key architect of India's constitution, the Law Minister in Nehru's interim cabinet, and a prominent leader of the so-called "untouchable" castes - formally placed

\footnotetext{
${ }^{26}$ King supra note 19, at 85. See also Harel supra note 17, at 170-171. Bagehot called the expressive provisions of a constitution its "dignified" parts, and thought they were essential for a constitution to gain authority: Walter Bagehot, the English Constitution 7 (Miles Taylor ed., 2001).

${ }^{27}$ Rahul Sagar \& Ankit Panda, Pledges and Pious Wishes: The Constituent Assembly Debates and the Myth of a "Nehruvian" Consensus, 14 India rev. 203 (2015). On the founding debates generally, see the Indian Constituent assembly: deliberations on democracy (Udit Bhatia ed., 2018).

${ }^{28}$ Winston Churchill, Churchill in his own words 163 (Richard Longworth ed., 2008).

29 James Chiriyankandath, "Creating a Secular State in a Religious Country": The Debate in the Indian Constituent Assembly, 38 Commonwealth \& Comp. pol. 1, 5 (2000).

${ }^{30}$ Granville Austin, the Indian Constitution: Cornerstone of a nation $12-14$ (1966). Ambedkar himself, a political opponent of the Congress, was elected with Congress's support after he lost his seat due to the country's partition.
} 
the draft constitution (DC) before the constituent assembly on November 4, 1948, eight months after its release for public comment. ${ }^{31}$ Various aspects of the DC had been drafted in different sub-committees of the assembly, and then finalized into one document by the drafting committee, under Ambedkar's chairpersonship. The document had drawn upon a long history of proto-constitutional thinking in India, primarily in the Congress Party, leading up to independence in August 1947; ${ }^{32}$ and on comparative constitutional practices, mainly from Western democracies. ${ }^{33}$ The DC was, on the whole, a liberal, secular, egalitarian, democratic, quasi-federal document, with entrenched civil and political rights, limited minority protections (non-discrimination, religious freedom, and cultural autonomy, but without special political representation), ${ }^{34}$ and social and redistributive directives to the state to achieve "economic democracy." "35 It sought to forge a common national identity for Indian citizens based on the jus soli principle, i.e., citizenship tied to the land rather than to ethnicity. As Jayal explains, "In the absence of a singular ethnocultural basis for nationhood, the Indian nation was substantially a political entity under construction." 36 While the place of liberalism in Indian political thought is complicated and seriously contested, ${ }^{37}$ the DC opted for liberal institutions such as fundamental human rights, common citizenship, and state secularism. I will refer to the group of influential members of the assembly - such as Ambedkar, Nehru, and Gopalaswamy Ayyangar-who were senior politicians involved in various subcommittees of the assembly, as the defenders of the DC. To the extent that this is an ideologically coherent group, they were pragmatists who subscribed to democratic constitutionalism. ${ }^{38}$

The DC got an extremely hostile reception from three powerful groups in the assembly: socialists, Gandhians, and cultural nationalists. It became clear quickly that these three challengers had to be carried along if the constitution were to be acceptable to all. The labels I have stuck on the dissenting groups are rather loose, and not unproblematic. Like the "defenders," these "groups" are, by no means, insular, and many members straddle multiple ideological worlds. Even so, the labels are a useful heuristic. Each of them had a strong presence within the broad church that Congress was, but socialists and the cultural nationalists were also influential outside the Congress Party. The socialists benefited

\footnotetext{
317 CAD, Nov. 4, 1948, 31.

32 Rohit De, Constitutional Antecedents, in the oxford handbook of the Indian Constitution 17 (Sujit Choudhry, et al. eds., 2016).

${ }^{33}$ Chiriyankandath, supra note 29, at 6. See also Javed Majeed, "A Nation on the Move”: The Indian Constitution, Life Writing and Cosmopolitanism, 13 life writing 237, 241 (2016). Majeed describes the Indian Constitution as a "cosmopolitan and transnational dialogue."

${ }^{34}$ On group rights and liberalism in the Indian constituent assembly in particular, see Rochana Bajpai, debating difference: group right and liberal democracy In India 76 (2011). Special political representation was generally denied to religious and linguistic minorities but was provided for the so-called "untouchable" castes and certain indigenous tribes.

35 "By parliamentary democracy we mean 'one man, one vote' . . it is also the desire that we should lay down as our ideal economic democracy ...., whereby, so far as I am concerned, I understand to mean, 'one man, one value"": 7 CAD, Nov. 19, 1948, 494 (Ambedkar). The reports actually say "vote" rather than "value," but this must be a mistake. This was confirmed by H. V. Kamath's speech, which quotes him: "Dr. Ambedkar said that to his mind, political democracy means one man, one vote; economic democracy means one man, one value." 7 CAD, Nov. 23, 1948, 33 (Kamath).

${ }^{36}$ Niraj Gopal Jayal, Citizenship and Its discontents: an Indian history 52 (2013).

${ }^{37}$ Christopher Bayly, recovering liberties: Indian thought In the age of liberalism and empire (2012); Partha Chatterjee, Secularism and Tolerance, in secularism and Its Critics 350 (Rajeev Bhargava ed., 1998); see also Bajpai, supra note 34 at, 96.

${ }^{38}$ Valerian Rodrigues, Good Society: Rights, Democracy and Socialism, in Ambedkar in retrospect 144 (Sukhdeo Thorat \& Aryama eds., 2007). Austin, supra note 31, at 42.
} 
from the global political turn leftward after World War II that intensified with the start of the process of decolonization around the same time. Gandhians sought reflected glory the immense personal aura of the recently assassinated Father of the Nation who was instrumental in securing India's independence. Cultural nationalists hoped to find their strength in the Hindi-speaking Hindu majority of the partitioned country. Although it is difficult to say how far they would have been willing to go to stall the constitutional process, and how successful they might have been in challenging Nehru's charismatic appeal, they seem to have had sufficient mischief-making power to merit accommodation. To an assembly that had witnessed the devastating impact of the Muslim League's boycott of its proceedings before Partition which was followed by the terrible events around Partition, keeping everyone else on board must have been a particularly pressing concern.

Let us start with the socialists. These members of the assembly, like D. S. Seth and T. Shah, leaned further left of an already Fabian/Laski-ite majority in the assembly, ${ }^{39}$ and would have preferred a full-blown socialist constitution. The Socialist Party had (after some equivocation) boycotted the assembly because the latter wasn't elected on universal suffrage, ${ }^{40}$ so the "socialists" we discuss here are the those who belonged to other parties and wanted not just a socialist government but also a socialist constitution. Their key demands included a constitutional mandate for the nationalization of the means of production, prohibition of private monopolies, co-operative organization of industry and agriculture, and other such socialist economic policies. ${ }^{41}$ They also wanted the right to work and education to be recognized as fundamental rights rather than directive principles. ${ }^{42}$ The strength of this feeling was reflected in K. T. Shah's amendment to draft article 1, seeking to describe India as a socialist state. ${ }^{43}$ While the DC already included some socialist demands as directive principles, the other two groups had stronger reasons to feel comprehensively excluded from the DC.

Gandhians coalesced around Mahatma Gandhi's anti-modern localist vision of a radically decentralized India: a union of autonomous, communitarian, simple, and autarkic village republics, where the slaughter of cows - revered by the Hindus - and alcohol consumption would be prohibited, and small-scale cottage industry and subsistence farming would ensure economic self-sufficiency. ${ }^{44}$ The DC, on the other hand, envisaged a powerful center, with relatively weak states and no provision for local government. The Nehruvian vision of a strong, cosmopolitan state with a centrally planned economy - that the DC facilitated - was particularly at odds with the Gandhian ideal of an anti-modern, anti-state autarky. As Mahavir Tyagi lamented, "I see nothing Gandhian in this Constitution." 45 Ambedkar's tactless description of the village as "a sink of localism, a den of ignorance, narrow-mindedness and communalism" 46 drew much hostility from the three dissenting groups, which made common cause on the

\footnotetext{
${ }^{39}$ Austin, supra note 30 , at 41 .

${ }^{40} \mathrm{Id}$. at 14.

417 CAD, Nov. 5, 1948, 399 (K. T. Shah); 7 CAD, Nov. 19, 486 (D. S. Seth); 7 CAD, Nov. 22, 1948, 506508 (K. T. Shah).

427 CAD, Nov. 5, 1948 (D. S. Seth).

437 CAD, Nov. 5, 1948, 399. This goal will be realized by the 42nd Amendment to the Constitution in 1976, under Indira Gandhi’s premiership.

447 CAD, Nov. 9, 1948, 359-362 (Mahavir Tyagi).

457 CAD, Nov. 9, 1948, 360.

467 CAD, Nov. 4, 1948, 39 (Ambedkar).
} 
localism question. ${ }^{47}$ It was the socialist K. T. Shah who moved to amend article 1 to require the establishment of village "panchayats" (units of local rural government) within ten years of the constitution. ${ }^{48}$

The majoritarian cultural nationalists imagined Indian nationhood in emphatically Hindu terms and made strong assimilationist demands on minorities. Although the main cultural nationalist party - the Hindu Mahasabha — was nominally absent from the assembly, three of its members were elected on other platforms, including two on the Congress ticket. ${ }^{49}$ Their meager numbers made little difference though, as the Congress itself had staunch cultural nationalists like Purushottam Das Tandon within its ranks. They agitated for an "indigenous" name for the country ("Hindustan" or "Bharat"), ${ }^{50}$ a national language (Hindi), a national script ("Devanagari"), a national anthem ("Vande Mataram"), a national flag ("Sudarshan"), and a uniform civil code (to replace religionbased "personal laws"), all of these framed in majoritarian terms. ${ }^{51}$ In fact, S. L. Saksena moved an amendment to enshrine a whole new Chapter 1A to the DC, which was essentially a Hindu-Hindi majoritarian cultural manifesto for the identity of the new state. ${ }^{52}$ The cultural nationalist sentiment was best captured by Seth Govind Das, who thundered: "we have accepted our country to be a secular state; but we never thought that that acceptance implied the acceptance of the continued existence of heterogenous cultures ... We do not want it to be said that there are two cultures here." $" 53$

The battle lines were drawn early, as soon as the assembly began debating Ambedkar's motion. Each of these influential dissenting groups found little to be pleased about, and wrecking amendments were moved to the very first provisions of the DC. They were all acutely aware of the defenders' Achilles' heel: the assembly was constituted by indirect elections on a franchise limited by property, tax, and education, in the dying days of the colonial empire, rather than through direct universal adult suffrage. This made it easy for them to portray the DC as "imported from outside and built from the above downwards," populist groups claimed to speak for the people, or, at least, the "real" people of Indiathe poor if you were socialist, the villagers if you were Gandhian, and North Indian Hindus if you were a cultural nationalist. The transaction cost of settling India's constitution was extremely high.

Even so, these groups did agree with the defenders on two things. First, almost all members of the constituent assembly signed up to democracy, and were united in their strong preference for politics over violence as the mechanism for resolving their

\footnotetext{
${ }^{47}$ For examples of the backlash, see 7 CAD, Nov. 5, 1948, 219 (H. V. Kamath); 7 CAD, Nov. 22, 1948, 523 (Seth Govind Das); 7 CAD, Nov. 5, 1948, 213 (S. L. Saksena).

487 CAD, Nov. 5, 1948, 426 (K. T. Shah).

49 Austin, supra note 30 , at 15 .

507 CAD, Nov. 8, 1948, 342 (Govind Malviya).

517 CAD, Nov. 5, 222-223 (Seth Govind Das); 7 CAD, Nov. 6, 1948, 275-279 (Thakur Das Bhargava). The nationalists were divided on the Uniform Civil Code: some, like K. M. Munshi supported it: 7 CAD, Nov. 23, 1948, 546-548 (K. M. Munshi). But several Hindu nationalists would later strongly oppose Ambedkar's efforts to reform Hindu family law, leading to his resignation as Law Minister in 1951: Anupama Rao, the Caste Question: Dalits and the politics of modern India 168 (2009); Jaffrelot supra note 4 , at $114-117$.

527 CAD, Nov. 5, 1948, 415.

539 CAD, Sept. 12, 1949, 1328.

547 CAD, Nov. 5, 1948, 212 (D. S. Seth).

557 CAD, Nov. 5 1948, 219 (H. V. Kamath).
} 
disputes. Gandhi's successful non-violent struggle against the colonial Empire must have strengthened the ideological aversion to organized political violence. Post-partition bloodshed did not leave much appetite for more. The belief of the dissenters that they had the "people" behind them might even have encouraged them to accept programmatic directives in a democratic constitution, on the assumption that the political realization of their respective agendas would be relatively straightforward as long as the constitution permitted (or, better still, directed) such realization. The main exception to this consensus against violence was the Communist Party of India, which - although marginally represented in the constituent assembly-launched an armed insurrection in 1948, only to withdraw it in 1950 to fight the first general elections. ${ }^{56}$

Second, given the appalling living conditions of the majority of the people in the country, the framers understood the burden of the expectations they all carried, and instinctively knew that the new constitution had to be transformative if it had to have any durability or legitimacy. ${ }^{57}$ Indeed, writing pseudonymously almost a decade before he would actually become prime minister, Jawaharlal Nehru was reflective enough to see his own popularity as a threat to democracy. ${ }^{58}$ India's first prime minister knew full well that democracy must deliver real social transformation if India was to avoid populist authoritarianism: a fear his daughter Indira Gandhi would realize disastrously, if briefly, a few decades hence. The great storyteller Manto passed a devastating verdict on the reform-oriented Government of India Act 1935: "What new constitution? It's the same old constitution, you fool." 59 The framers could not afford a similar assessment of the constitution they were drafting.

The political context of the late 1940s postcolonial India was also relevant: Mahatma Gandhi had recently been assassinated by a Hindu nationalist, Partition riots had seen mass population transfers and the murder and rape of millions of people across India and Pakistan, the new nation-states had already been to war over Kashmir, the fear of a Communist uprising was rife, ${ }^{60}$ Cold War between the USA and the USSR had begun on the heels of the disastrous World War II, ${ }^{61}$ and a few of the 562 semi-autonomous princely states were toying with independence. All this at a time when the colonial state had partitioned the country on religious lines and transferred power in such a remarkable hurry and with such unconscionably meager preparation that any new indigenous administration would have had enough on its plate even without the accompanying litany of horrors. ${ }^{62}$ This is the context in which bitterly divided Indians decided to write up a constitution, adopting universal adult suffrage for a huge, illiterate, and extremely poor population with vast cultural, linguistic, and religious diversity. As politicians dealing

\footnotetext{
${ }^{56}$ Ramachandra Guha, India after Gandhi: The History of the World's Largest Democracy (2008).

577 CAD, Nov. 23, 1948, 533 (H. V. Kamath): "If political democracy is allowed to evolve, to grow, into economic, social democracy, then we would not have strife, we will not have wars, we will not have a totalitarian form of Government."

${ }^{58}$ Chanakya, The Rashtrapati, 62 Mod. Rev. (Calcutta) 546 (Nov. 1937).

59 Saadat Hasan Manto, The New Constitution, in Mottled Dawn: Fifty Sketches and Stories of Partition 165,175 (1997).

607 CAD, Nov. 22, 1948, 522 (T. Prakasam): "Let me tell you above all that Communism - the menace the country is facing ... Communism can be checked immediately if the villages are organized in this manner and if they are made to function properly."

617 CAD, Nov. 23, 1948, 531 (M. Tyagi): "In Russia, they say, there is already achieved economic democracy, but this economic democracy in Russia has concentrated all power in the hands of the State, with the result that the State has become autocratic."

62 On the immediate political and economic context, see Austin, supra note 30 , at $43 \mathrm{f}$
} 
with day-to-day problems, the members of the assembly would have been well aware of the challenges that faced India - although acutely aware of its distinct roles, ${ }^{63}$ the constituent assembly doubled up as independent India's interim legislative assembly and supplied its interim government headed by Nehru. They hoped not only that the constitution would endure, ${ }^{64}$ but also that it would secure a state that would strive towards their respective partisan utopias.

\section{Directive principles in the Indian Constitution}

Directive principles emerged as a potential tool to secure the consent of the three dissenting groups — socialists, Gandhians, and cultural nationalists — soon after the assembly started its consideration of the DC. As early as November 5, a day after the discussion on the DC began, Ambedkar assured the socialists that much of their agenda was already contained in the chapter on directive principles; ${ }^{65}$ Ananthasayanam Ayyangar - another prominent leader not to be confused with Gopalaswami Ayyangarargued on the same day that the faction-ridden village life needed to be gradually prepared for democratic principles, requesting the withdrawal of decentralization amendments in lieu of a promise that he himself would move an amendment to that effect as a directive principle. ${ }^{66}$

That the directives could have been a conscious strategy of the defenders to accommodate the dissenters is also hinted at by another fact: in its eight sessions between November 4 and November 18, 1948, the Assembly considered the motion re the DC and the four introductory articles constituting the state. During these eight sessions, the hostility of the three groups to the DC had become more than apparent. Towards the end of the session on November 18, 1948, the Vice President, who was chairing the session, declared that the discussion on the following day-November 19 would open with the consideration of part IV of the DC containing the directives, rather than the structurally prior parts II and III relating to citizenship and fundamental rights, respectively. Some members understandably protested against this sudden and inexplicable change of schedule. Whether this change in schedule was designed to get the hostile groups on board before moving on to the other parts of the constitution is unclear from the debates, but we have good reasons to speculate.

India borrowed the concept of directive principles from the Irish Constitution and the International Bill of Rights drafted by Hersch Lauterpacht in $1945 .{ }^{67}$ Most of the directive principles in the Indian Constitution are to be found in chapter IV of the document. Some, however, such as the directive to promote the spread and enrichment of

\footnotetext{
${ }^{63}$ As a member referred to "the government" when the house sat as the constituent assembly, another was quick to chide him: "What has this House got to do with the Government?" 7 CAD, Nov. 19, 1948, 490 (T. T. Krishnamachari).

${ }^{64}$ This hope wasn't shared by all. In fact, Nehru himself thought that this Constitution would be temporary: "I do think that [at] some time or other in the future we may have to summon our own proper revolutionary Constituent Assembly": Dorothy Norman, Nehru, First Sixty Years 235 (1965).

657 CAD, Nov. 5, 1948, 402 (Ambedkar).

667 CAD, Nov. 5, 1948, 428 (M. Ananthasayanam Ayyangar).

67 Jayal, supra note 36 , at 145 .
} 
Hindi language, may be found elsewhere. ${ }^{68}$ Most of the directives - as originally enacted in the 1950 Constitution - can be classified into three categories based on the degree of agreement surrounding their content in the assembly debates. Some directivesconcerning foreign policy in the Cold War world, ${ }^{69}$ protection of national monuments, ${ }^{70}$ and separation of the lower judiciary and the executive ${ }^{71}$ - are not included in the classification that follows as they are not directly relevant to the account in this article.

The agreement-sensitive classification that follows tracks the degree of consensus around specific directives, rather than disagreement over the status and place of directive principles generally. Some members were against the whole idea of directive principles: either because they (or at least the less controversial ones initially proposed in the DC) were "obvious truths" that did not need legislating 72 or because they were "certain principles of a particular school of thought" and therefore "contrary to the principles of parliamentary democracy,"73 or because they should have been guaranteed as fundamental rights instead. ${ }^{74}$ We will ignore this sort of meta-disagreement.

An agreement-sensitive classification results in three categories of directives: first, the uncontested directives, over which there was almost no disagreement. The second category - the partially contested directives - saw broad agreement over the general goal of achieving social, economic, and political justice but deep disagreement over the best means to secure that. In the final category were the deeply contested directives, the legitimacy of whose very goals were seriously disputed, and almost all of which were later additions to the DC. ${ }^{75}$ It is interesting to note that Weis identifies three distinct reasons why framers might wish to shield constitutional norms from judicial enforcement: resource constraints, information constraints, and deep moral disagreements, ${ }^{76}$ which seem to correlate neatly with the uncontested, the partially contested, and the deeply contested directives, respectively.

The first class of these directives (the uncontested directives) includes those over which there was no or negligible disagreement in the assembly: neither were the stipulated goals disputed, nor was there any serious debate over the means for securing them. These directives were contained in the DC and made it to the final document more or less unscathed. The most important set of directives in this category relate to a basic social minimum, guarantees that are part of Rawlsian constitutional essentials. These included the right to livelihood, ${ }^{77}$ equal pay for equal work for men and women, ${ }^{78}$ right to work

\footnotetext{
${ }^{68}$ India Const. art. 351. See also art. 350A directing the state to endeavor "to provide adequate facilities for instruction in the mother-tongue at the primary stage of education to children belonging to linguistic minority groups."

${ }^{69}$ India Const. art. 51.

70 India Const. art. 49.

${ }^{71}$ India Const. art. 50.

727 CAD, Nov. 5, 1948, 225 (Naziruddin Ahmad).

737 CAD, Nov. 19, 1948, 488 (Mahboob Baig Sahib Bahadur).

${ }^{74}$ K. T. Shah, Minutes of Dissent to the Report of the Sub-Committee on Fundamental Rights, April 1720, 1947, in 2 The Framing of India's Constitution: Select documents 191, 192 (B. Shiva Rao ed., 1967); 7 CAD, Nov. 19, 1948, 473 (Kazi Syed Karimuddin).

${ }^{75}$ For another classification of the Indian directives, see Bertus de Villiers, Socio-Economic Rights in a New Constitution: Critical Evaluation of the Recommendations of the South African Law Commission, 3 J.S. Afr. L. 35-37 (1992).

${ }^{76}$ Weis, supra note 24, at 935.

${ }^{77}$ India Const. art. 39(a).

${ }^{78}$ India Const. art. 39(d).
} 
and unemployment benefit, ${ }^{79}$ maternity relief, ${ }^{80}$ a living wage, ${ }^{81}$ and free and compulsory education for children. ${ }^{82}$ The main debate on these provisions was over their status, with several members demanding that they be enacted as immediately enforceable fundamental rights. ${ }^{83}$ The main reason for enacting them as directives was that some lawyers prevailed in convincing the drafting committee that guaranteeing them as rights was not "practicable" as they are "not normally either capable of, or suitable for, enforcement by legal action." 84 This category includes the directives that the Indian Supreme Court would later go on to read into the fundamental right to life guaranteed under article 21 anyway. ${ }^{85}$

The second category mostly contains directives relating to distributive justice (the partially contested directives). For this category, there is a broad agreement in the assembly over a general aim that the state should seek, encapsulated in article 38: "The State shall strive to promote the welfare of the people by securing and protecting as effectively as it may a social order in which justice, social, economic and political, shall inform all the institutions of the national life."

Article 38 may even be considered the master directive, its abstract pursuit of welfare and justice never contested. Every transformative visionary believed that their preferred route would lead to this ultimate utopia. It might even be seen as having some controlling impact on how all other directives were justified in the assembly, i.e., as particular manifestations of this overall goal. But beyond this agreement over the abstract goal of socio-economic justice, there were deep divisions over the appropriate means that would get us there.

A few further distributive justice directives, slightly more specific, also make it to the final text: one to secure that "ownership and control of the material resources of the community are so distributed as best to subserve the common good," 86 another to prevent "the concentration of wealth and means of production to the common detriment," third to "endeavour to secure ... a living wage ... and, in particular, ... promote cottage industries on an individual or co-operative basis." 88 The reference to cottage industries was a later addition following a floor amendment. Viewed on their own they may sound socialistic, but these directives did not include some of the more specific and farreaching socialist demands (nationalization of resources, prohibition of private monopolies, co-operative farms and industry, explicit adoption of state socialism). ${ }^{89}$

Given that context, these were relatively weak or open-ended means of securing

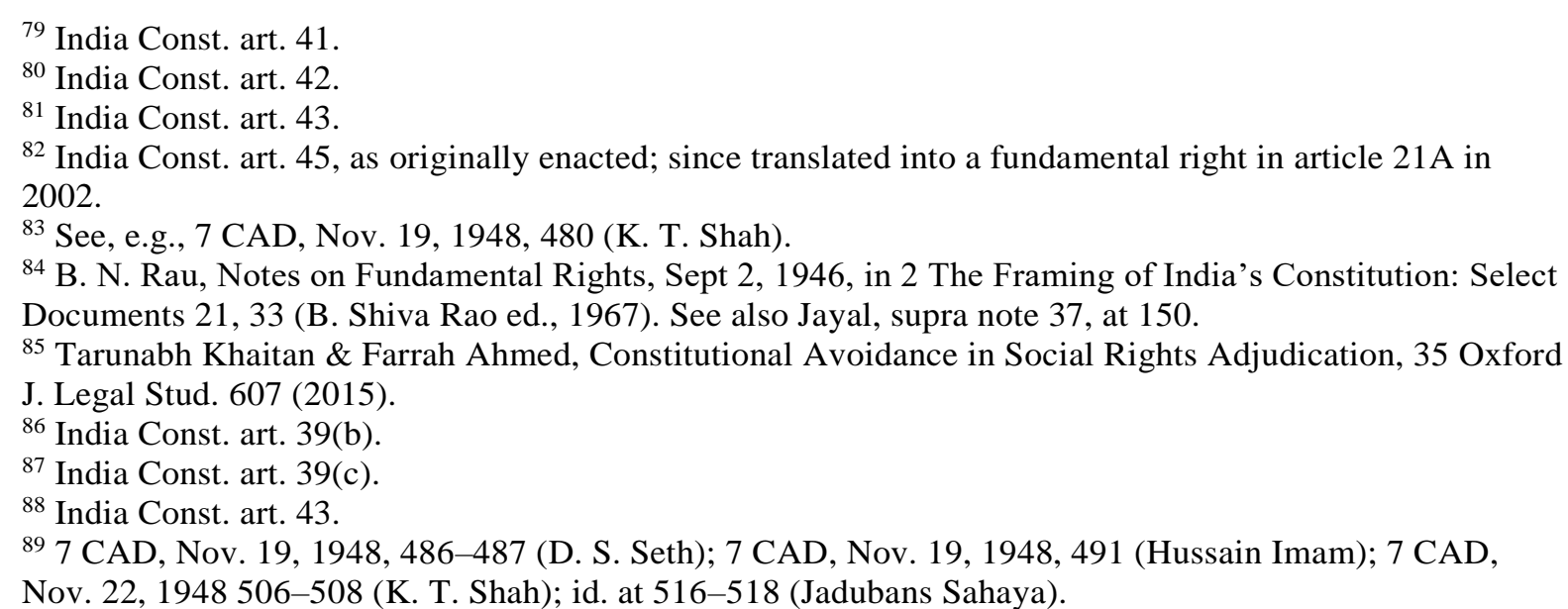


distributive justice. Ambedkar steadfastly opposed all socialist attempts to specify the means of achieving economic democracy. In the quote that follows, he emphasized that the route to economic democracy must be ascertained through political democracy. He asked rhetorically:

... having regard to the fact that there are various ways by which economic democracy may be brought about, we have deliberately introduced ... language that ... is not fixed or rigid. We have left enough room for people of different ways of thinking ... to strive in their own way, to persuade the electorate that it is the best way of reaching economic democracy. ${ }^{90}$

The third category of directives (the deeply contested directives) were those whose goals themselves were vehemently contested. Most of these directives were later additions to the DC, through amendments from the floor, as concessions that the defenders made to various dissenting groups. These included a directive to "take steps to organise village panchayats ... as units of self-government," "91 to "endeavour to secure ... a uniform civil code," 92 to improve public health and "in particular ... endeavour to bring about prohibition of the consumption ... of intoxicating drinks," animal husbandry on modern and scientific lines and ... in particular, take steps for ... prohibiting the slaughter of cows," to develop it" by assimilating Hindustani, Sanskrit, and other Indian languages. ${ }^{95}$

Most of the advocates of these divisive directives belonged to one of the three populist groups that lost out overall in the constitutional bargain: Gandhians, socialists, and cultural nationalists. These directives acknowledged and accommodated some of their agendas in the constitution and thereby mitigated their opposition to the DC. This accommodation was, however, a qualified one: it was contained and incrementalist. The next section will show how.

\section{Incrementalism and containment}

The obvious way to secure the consent of any dissenting group is through accommodation of their normative agenda. As we saw in the previous section, this is exactly what the framers of the Indian Constitution did, by incorporating some of the key socialist, Gandhian, and cultural nationalist demands as directive principles in the constitution. But straightforward accommodation in the face of deep disagreement creates a new problem as it solves another, because accommodation of one group is likely to anger another. Taking everyone along requires a fine balancing act, one that offers enough sops to the dissenters, but not so many that their detractors in turn feel tempted to jump ship. Furthermore, the defenders' conception of legitimacy constraints would also place limits on how far they can go with accommodating illiberal dissenters. Possibly for this reason, the framers resisted all attempts to incorporate these radical agendas in the preamble or the opening provisions of the constitution, recognizing them

\footnotetext{
907 CAD, Nov. 19, 1948, 494 (Ambedkar).

${ }^{91}$ India Const. art. 40.

92 India Const. art. 44.

${ }^{93}$ India Const. art. 47.

94 India Const. art. 48.

95 India Const. art. 351.
} 
in the expressively less salient directives instead. The framers also used two key techniques to achieve a balanced accommodation: containment and constitutional incrementalism. Containment is a strategy of deradicalization: even as the agendas of the dissenters were accommodated, the defenders defanged and contained them as far as they were able to. The key containment tools they used were dilution, instantiation, and qualification. Constitutional incrementalism is a strategy of deferral: while the agenda is accommodated, its realization is postponed to a future date, thereby reducing the tension somewhat. Both tools seek to reduce the high decision costs associated with constitutionmaking in a deeply divided context. I do not claim that either tool is exclusive to directive principles. My claim in what follows is simply that the contested directives in India tended to be contained, and that directive principles, by virtue of being directive principles, generally entail constitutional incrementalism (even though there may be other tools to achieve such incrementalism). The following subsections will examine each of these tools in some detail.

\subsection{Containment}

Although these bitterly divisive directives did make their way into the constitution, the defenders - chiefly Ambedkar - made a number of strategic interventions to contain them, take the sting out somewhat, and move each radical agenda somewhat closer to the center ground. The containment tools they used were dilution, instantiation, and qualification.

Dilution was used with respect to the Gandhian directive concerning village panchayats. Many members wanted the directive to specify not only the localist goal of rural selfgovernment but also the autarkic objective of self-sufficiency. ${ }^{96}$ Fully conscious of the backlash that followed his remarks about villages while introducing the DC, Ambedkar lost no time in assenting to the most diluted amendment that sought self-governing panchayats, without any mention of self-sufficiency. ${ }^{97}$ The demand for a directive to promote co-operative cottage industries was diluted by Ambedkar adding "individual or" before the phrase "co-operative," to permit both forms of organizations. ${ }^{98}$ The relevant part of the diluted directive finally required that "the State shall endeavour to promote cottage industries on an individual or co-operative basis in rural areas." Dilution was used in provisions other than directives too. Ayyangar, for example, moved for the recognition of Hindi not as a "national" language — as the cultural nationalists demanded - but rather as an "official" language of the Union. ${ }^{99}$

Instantiation was another strategy that Ambedkar used frequently to temper the radicalism of a demand. He did so by making the radical demand an instance of a more general (and more generally accepted) principle, thereby giving the broader acceptable principle a controlling role in determining the meaning of the particular contested directive. He killed an attempt to introduce a self-standing directive on alcohol prohibition by successfully cutting a deal to have it introduced as a particular instance of

967 CAD, Nov. 22, 1948, 521-522 (T. Prakasam); 7 CAD, Nov. 22, 1948, 525 (V. Subramanian); 7 CAD, Nov. 22, 1948, 525 (L. Krishnaswamy Bharati).

977 CAD, Nov. 22, 1948, 520 (K. Santhanam).

987 CAD, Nov. 23, 1948, 535 (Ambedkar).

999 CAD, Sept. 12, 1949, 1318 (N. Gopalaswami Ayyangar). 
another general directive, one that required the state to raise nutritional standards and public health, ${ }^{100}$ joining the two directives with a cleverly introduced "in particular" at the last minute. ${ }^{101}$ The instantiated directive that became article 47 finally read: "The State shall regard the raising of the level of nutrition and the standard of living of its people and the improvement of public health as among its primary duties and, in particular, the State shall endeavour to bring about prohibition of the consumption ... of intoxicating drinks ..." (emphasis added).

Similarly, the socialist demand for the promotion of cooperative cottage industries in villages was tempered by making it a particular and illustrative instance of the general directive to secure a living wage and decent standards of living. ${ }^{102}$ The compromise formulation Ambedkar agreed upon with Thakur Das Bharagava made the prohibition of cow slaughter a particular means of seeking the general organization of agriculture and animal husbandry "on modern and scientific lines." 103 His acceptance of these instantiated directives facilitated the withdrawal of far more radical and self- standing versions of these objectives, and the controlling instantiation of these goals nested within broader-uncontroversial—goals left some hope for the dissenters.

On this reading, instantiation entailed particularization: comprehensive radical agendas were boiled down to single, specific, demands which would be difficult to expand upon or used to generate general principles. By contrast, consider the non- particularized accommodation of religious majoritarianism in Article 9 of the Sri Lankan Constitution. It directs the state to 'give Buddhism the foremost place', even as it qualifies this directive with an assurance of religious freedom to all.

Instantiation might in fact explain Ambedkar's odd understanding of the nature of the political duty that the alcohol prohibition directive imposed. Throughout the debates on the uncontested directives, Ambedkar had unwaveringly insisted that although not justiciable, the political duties imposed by the directives were real and the state had no option but to act: "It is the intention of this Assembly that in future both the legislature and the executive should not merely pay lip service to these principles enacted in this part, but that they should be made the basis of all executive and legislative action." 104

But when it came to the prohibition directive, he surprisingly had this to say in response to the liberal objections of Professor Khardekar:

There is ... no compulsion on the State to act on this principle. Whether to act on this principle and when to do so are left to the State and to public opinion. Therefore, if the State thinks that the time has not come for introducing prohibition or that it might be introduced gradually or partially, under these Directive Principles it has the full liberty to act. ${ }^{105}$

\footnotetext{
1007 CAD, Nov. 22, 1948, 501 (Ambedkar).

1017 CAD, Nov. 22, 1948, 566 (Ambedkar).

1027 CAD, Nov. 23, 948, 530 (T. A. Ramalingam Chattier); 7 CAD, Nov. 22, 1948, 535 (Ambedkar).

1037 CAD, Nov. 24, 1948, 568 (Bhargava and Ambedkar).

1047 CAD, Nov. 10, 1948, 476 (Ambedkar). See also 7 CAD, Nov. 19, 1948, 490 (K. Hanumanthaiya).

1057 CAD, Nov. 24, 1948, 566 (Ambedkar) (emphasis added). In this speech, Ambedkar appears to have confused B. H. Khardekar with another assembly member H. J. Khandekar - the liberal objections against alcohol prohibition were raised by the former.
} 
The part of this statement that suggests that the state has the liberty to decide when and how to act is in keeping with the partial deferral account that I will provide in the next subsection. But, the claim - that it is also open to the state to decide whether to act at all-seems surprising. It is clearly at odds with his earlier, and oft-repeated, claims about the nature of directive principles. It is true that Ambedkar is primarily a politician, and we need not expect him to always be coherent or consistent. Even so, we can read the two claims coherently if we accept that instantiation relegates the instantiated directive to be applicable only if, when, and to the extent that it serves the controlling general directive, which remains the primary duty of the state.

This reading is further supported by the manner in which the cow slaughter debate proceeded in the assembly. The directive on cow slaughter prohibition was controlled by a general directive to organize agriculture on scientific lines. Speaking in support of the directive, Thakur Dass Bhargava insisted that he did "not appeal to you in the name of religion; I ask you to consider it in the light of economic requirements of the country," mainly a secure supply of milk. ${ }^{106}$ In response, Syed Muhammad Saiadulla decried the hypocrisy of the Hindu nationalists using pseudo-scientific arguments to support the directive, asking them to come out openly by declaring their real religious motives upfront. ${ }^{107}$ The fact that Bhargava and others felt constrained to offer "scientific" reasons for prohibiting cow-slaughter suggests an acceptance of the controlling nature of the general directive to which the directive on the prohibition of cow slaughter was instantiated.

If this reading is correct, as I think it is, the framers accepted that the state's latent duty to prohibit the consumption of alcohol may kick in only if alcohol consumption becomes a threat to public health and nutritional standards; cow slaughter prohibition is required only when doing so is in service of organizing agriculture on scientific lines; cooperative cottage industries need support only if they help secure a living wage and a decent standard of living. Instantiation substantially transforms the nature of the political duty a directive imposes.

The third containment strategy-qualification - is most obvious in the language directive. The cultural nationalists wanted Hindi as the national language and the Muslim minority wanted Hindustani-a composite language comprising Hindi and Urdu. Some nationalists even wanted the classical language Sanskrit to be revived as a spoken language and adopted as a national one. So divisive was the issue that Maulana Abul Kalam Azad, a prominent Muslim Congress politician, had resigned from the drafting committee after it opted for Hindi as the official language. ${ }^{108}$ The compromise MunshiAyyangar formula concerning language policy included what became article 351: a rather complicated directive, requiring the union to "promote the spread of the Hindi language, to develop it so that it may serve as a medium of expression for all the elements of the composite culture of India, and to secure its enrichment by assimilating ... the forms, style and expressions used in Hindustani and in the other languages of India ..., and by drawing ... for its vocabulary, primarily on Sanskrit and secondarily on other

1067 CAD, Nov. 24, 1948, 570 (T. D. Bhargava).

1077 CAD, Nov. 24, 1948, 578 (S. M. Saiadulla).

1089 CAD, Sept. 13, 1949, 1456 (Azad). There was another linguistic battle between Hindi and English as the preferred official language: this was resolved through a "by-law" provision to be discussed in the next subsection. 
languages."109 The qualification of the support for Hindi with references to India's composite culture and Hindustani were partly in response to Azad's resignation, ${ }^{110}$ and allowed secularists like Nehru to reluctantly endorse it. ${ }^{111}$

These containment tools therefore allowed the framers to walk a fine line that the context necessitated. Combined with incrementalism, the effect was one of containing the radicalism of the populist demands not just at the constitutional moment but well into the political future. There were reasons to believe that the content of the constitutionalized directives would come to control the manner in which the demands can be articulated and the reasons for which they could be justified - for example, by inextricably linking the prohibition of cow slaughter to modern and scientific agriculture. Understood thus, containment gave something to the winners too, while accommodating the dissenters.

\subsection{Incrementalism}

A key technique to reduce decision costs in deeply divided societies is constitutional incrementalism. The key to incrementalist negotiation is that each group tests the incremental or marginal value of the proposal on the table: not whether the proposal is ideal objectively, but whether it is better than a plausible alternative. ${ }^{112}$ Under an incrementalist approach, "The test of a 'good' policy is typically that various analysts find themselves directly agreeing on a policy (without also agreeing that it is the most appropriate means to an agreed objective)." ${ }^{113}$ This idea of seeking political objectives through multiple small steps, characterized as "muddling through" by Charles Lindblom, has echoes in the later works of several other theorists. ${ }^{114}$ Incrementalism ensures that the winner does not take all, and that the losers are left with enough (either now or in the future) to agree to endorse the package. It should be obvious that incrementalism can be key to meeting the stability constraints for constitutions in deeply divided societies.

To the extent that constitutionalization usually comes with entrenchment and incrementalism requires a step-by-step approach to change, constitutional incrementalism may seem oxymoronic. It is not so. What constitutional incrementalism seeks to do is to transfer at least some of the decisional weight away from the present to the future, and away from the constitution to politics: i.e., adopting at least a two-step approach rather than doing all the heavy lifting at once. As Lerner puts it: "All constitutional strategies included in the incrementalist toolbox are intended to defer to the future controversial choices regarding the foundational aspects of the constitution in order to permit some form of agreement on a constitution to be reached." 115 As long as current losers believe they are likely to succeed in the future even as they lose right now, they may consent to an incrementalist settlement.

\footnotetext{
${ }^{109}$ India Const. art. 351 (emphasis added).

1109 CAD, Sept. 13, 1949, 1456 (Azad).

1119 CAD, Sept. 13, 1949, 1411 (Nehru).

${ }^{112}$ Charles Lindblom, The Science of "Muddling Through," 19 Pub. Admin. Rev. 79, 83 (1959). See also

Rawls, Political Liberalism, supra note 25, at 89f.

${ }^{113}$ Lindblom, supra note 112 , at 81 .

${ }^{114}$ See Cass Sunstein, Designing Democracy: What Constitutions Do 64f (2001); Hanna Lerner, Making Constitutions in Deeply Divided Societies (2011); Jeff King, Judging Social Rights 289f (2012); Dixon \& Ginsburg, supra note 10. Some of the literature specifically deals with transitional societies: Ruti G. Teitel, Transitional Justice 196 (2000).

${ }^{115}$ Lerner, supra note 114 , at 39.
} 
Another apparent contradiction may lie in using an "incrementalist" device to seek "transformation." However, as Lindblom explained, "incrementalism in politics is not, in principle, slow moving. It is not necessarily, therefore, a tactic of conservatism. A fastmoving sequence of small changes can more speedily accomplish a drastic alteration of the status quo than can an only infrequent major policy change ... incremental change patterns are, under ordinary circumstances, the fastest method of change available.... They do not rock the boat, they do not stir up the great antagonisms and paralyzing schisms as do proposals for more drastic change." 116 This, of course, may not always be the case. But at least sometimes, not only is incrementalism not in tension with transformative constitutionalism, it may even be the most efficient way of securing it. ${ }^{117}$ Indeed, the larger the scale of the transformation sought, the larger is the gap between the status quo and the end goal. The sheer impossibility of bridging this gap immediately would give reasons even to the staunchest advocates of the transformation to accept some deferral. For example, on the debate on official language, most Hindi-nationalists accepted that some time was required to get an administration that has transacted mostly in English to switch to Hindi, and also for residents of non-Hindi-speaking states to learn the language. ${ }^{118}$ Thus, far from being in tension with incrementalism, transformative constitutionalism seems to demand it. ${ }^{119}$

Dixon and Ginsburg provide an excellent account of a classic constitutional incrementalist tool: "by-law" clauses, through which "constitution-makers selfconsciously choose not to bind their successors"; instead they "explicitly delegate certain constitutional questions to future legislatures." ${ }^{120}$ By "deciding not to decide," they reduce the decision costs and potential error costs at the time of framing the constitution. Although Dixon and Ginsburg don't use the label "incrementalism," they locate "bylaw" clauses in the same family of decision-cost-reducing tools such as easy amendability, vagueness, and "sunset" provisions. ${ }^{121}$ Lerner adds ambiguity, opaqueness, and internal contradiction to this list of deferral tools. ${ }^{122}$ All these tools facilitate deferral of current, constitutional, controversies to future, political, ones.

Framers of the Indian Constitution understood the value of deferral. Nehru explicitly pleaded for the deferral of the language controversies before the assembly:

I would not have thought that this [linguistic reorganization of states] was a question of that primary importance, which must be settled here and now today. It is eminently a question which should be settled in an atmosphere of good-will and calm and on a rather scholarly discussion ... when heat and passion are there, the mind is clouded ... treat it as a thing which should be settled not in a hurry when passions are roused, but at a suitable moment when the time is ripe for it. The same argument ... applies to this question of [official] language ... if in trying to

\footnotetext{
${ }^{116}$ Charles Lindblom, Still Muddling, Not Yet Through, 39 Pub. Admin. Rev. 517, 520 (1979).

${ }^{117}$ See also Jeff King's advocacy of incrementalism in the judicial enforcement of social rights in constitutions that permit them to do so. See King, supra note 114.

1189 CAD, Nov. 13, 1949, 1443 (Purushottam Das Tandon).

${ }^{119}$ Even in the South African Constitution with judicially enforceable social rights, Jeff King describes the Constitutional Court's approach to these rights as incrementalist. See King, supra text accompanying note 114.

${ }^{120}$ Dixon \& Ginsburg, supra note 10 , at 637.

${ }^{121}$ Id. at 638 .

122 Lerner, supra note 114 , at 39.
} 
press for a change, an immediate change, we get wrapped up in numerous controversies and possibly even delay the whole Constitution, ... it is not a very wise step to take ... Because it is vital, it is also an urgent matter; and because it is vital, it is also a matter in which urgency may ill-serve our purpose. ${ }^{123}$

The assembly listened by enacting a slew of by-law clauses. Article 3 of the constitution provided that "Parliament may by law" reorganize states, normally after consultation with the states concerned. Article 343 recognized Hindi as the "official language" of the union, but provided for the continuation of English for a period of fifteen years which may be extended by parliament "by law." As it happened, after considerable heat and passion in struggles waged on the streets in the 1950s, parliament did reorganize the states six years after the constitution came into force, and it did extend the use of English as an official language before the sunset clause expired. What is pertinent to note is that the constitution did not require parliament to do any of this: these "by-law" clauses were constitution permissions, not mandates. We could describe this as a full deferral: a future parliament had the full power to decide whether to act and how to act. The constitution merely settled the default position if parliament did nothing. On the organization of states, the constitutional default was the continued existence of the existing state boundaries. On official language, the constitutional default was the expiry of English's status as an official language after fifteen years. But beyond setting a default, the constitution did not direct parliament in any manner. The determination of whether and how was left to politics. Even the question of when to act was left entirely open on the reorganization question, although the constitution did set parliament a deadline of fifteen years with respect to the official language question.

By-law clauses were not the only deferral tool used in the Indian Constitution.

Chiriyankandath explains how ambiguity was used to adopt multiple variants of secularism in the Indian Constitution, so that most groups felt able to sign up to their own interpretations. ${ }^{124}$ Abstraction was specifically adopted while specifying distributive justice goals. Ambedkar resisted most specification attempts by the socialists by insisting that the clauses "have been drafted in general language deliberately for a set purpose"125; that purpose evidently being to secure what Sunstein would call an "incompletely theorized agreement" between divided groups. ${ }^{126}$ Even contradiction was used: some of the socialist directives were in tension with the right to property, ${ }^{127}$ and Hindumajoritarian directives potentially contradicted freedom of trade ${ }^{128}$ and freedom of religion. ${ }^{129}$ These tensions were noted in the Assembly debates, and would be fertile battleground for continuing legal and political debates for decades after independence. ${ }^{130}$

\footnotetext{
1237 CAD, Nov. 8, 1948, 320-321. See also T. Prakasam, welcoming the compromise directive on panchayats which allowed the assembly to proceed "without interrupting the progress of the Constitution at this stage." 7 CAD, Nov. 22, 1948, 521-522.

${ }^{124}$ Chiriyankandath, supra note 29.

1257 CAD, Nov. 22, 1948, 519 (Ambedkar).

${ }^{126}$ See Sunstein, supra note 114, at 50: where parties agree to constitutional practices even though they have different underlying reasons for supporting it.

${ }^{127}$ Former article 19(1)(f), since relegated to a mere "constitutional" (rather than a fundamental) right in article 300A. See India Const. arts. 19(1) (f), 300A.

${ }^{128}$ India Const. art. 19(1)(g).

${ }^{129}$ India Const. art. 25.

${ }^{130}$ See Jayal, supra note 36, at 158f.; Bhatia, supra note 8; Namita Wahi, Property, in The Oxford Handbook of The Indian Constitution 943 (Sujit Choudhry, Madhav Khosla, \& Pratap Bhanu Mehta eds., 2016); Flavia Agnes, Personal Laws, in The Oxford Handbook of the Indian Constitution 903 (Sujit
} 
Above all, the easy amendability enshrined in article 368 was itself a constitutional incrementalist device. ${ }^{131}$ For most matters that did not affect the states, future parliaments - elected directly on universal franchise-were vested with the constituent power to amend the constitution through a simple majority. Nehru explicitly recognized this as necessary in part to make up for the democratic deficit in the constituent assembly. ${ }^{132}$ Losing groups knew they had the opportunity to revisit aspects of the constitutional settlement. This is indeed what happened. Many of the socialist demands, for example, would be satisfied by the 42nd Amendment to the constitution in 1976, and the Gandhian localist agenda would be constitutionalized by the 73rd Amendment in 1992.

What makes directive principles, qua directive principles, a deferral device? A few scholars have recently mentioned their role as deferral tools in the Indian context, most of them incidentally. ${ }^{133}$ Lerner identifies a reason why directive principles, as such, are a deferral tool - she claims it is down to their non-justiciability. Even as she makes this connection, a clear explanation for the same is not forthcoming. Although nonjusticiability is important, it is in fact the programmatic character of directives which really explains the inherent incrementalism of such principles. Recall that this feature acknowledges that there will be a time lag between the adoption of a directive and its ultimate realization. It is true that some directives can be realized relatively quickly: a uniform civil code can simply be legislated. But we are not, for the moment, speaking of incrementalism generally but of constitutional incrementalism in particular. All that this requires is the deferral of a problem from the current constitutional domain to a future (in this case, political) domain. Constitutional incrementalism entails at least two steps in problem-solving: a constitutional recognition of the problem and a subsequent political resolution of the same. This is exactly what the deeply divisive directives achieved. By enshrining the prohibition of cow slaughter and alcohol consumption, the enactment of a uniform civil code, and the accommodation of the cooperative and other socialist agendas as directives, the constitution ensured that these issues will remain on the political agenda of the future state. But by recognizing them as directives, the framers simultaneously avoided having to make a costly political decision on these divisive questions at a fraught constitutional moment. These issues had to be addressed, but not now; by future politics rather than by the present constitutional text.

Having said that, directive principles do not just envisage constitutional incrementalism, they also require political incrementalism. The political duty they impose is akin to "progressive realisation" duty recognized with respect to social rights in the South

Choudhry, Madhav Khosla, \& Pratap Bhanu Mehta eds., 2016); Shraddha Chigateri, Negotiating the "Sacred" Cow: Cow Slaughter and the Regulation of Difference in India, in Democracy, Religious Pluralism and the Liberal Dilemma of Accommodation (Monica Mookherjee ed., 2011).

${ }^{131}$ The Supreme Court put major constraints on Parliament's amendment power in Kesavananda Bharati v. State of Kerala, 4 S.C.C. 225 (1973).

1327 CAD Nov. 8, 1948, 323 (Nehru): "while we, who are assembled in this House, undoubtedly represent the people of India, nevertheless I think it can be said, and truthfully, that when a new House, by whatever name it goes, is elected in terms of this Constitution, and every adult in India has the right to vote- man and woman - the House that emerges then will certainly be fully representative of every section of the Indian people. It is right that House elected so-under this Constitution of course it will have the right to do anything - should have an easy opportunity to make such changes as it wants to."

${ }^{133}$ Lerner's account is, relatively speaking, the most developed in this regard: see Hanna Lerner, The Indian Founding: A Comparative Perspective, in The Oxford Handbook of The Indian Constitution 55, 67 (Sujit Choudhry, Madhav Khosla, \& Pratap Bhanu Mehta eds., 2016). In a public lecture in Melbourne in April 2016, Sudhir Krishnaswamy also referred, in passing, to directive principles as deferral devices. 
African Constitution. ${ }^{134}$ The use of programmatic verbs such as "strive," "direct," "take steps," and "make effective provisions for" by the Indian directives suggests that they expect the future political realization of these directives to also be a multi-step process rather than a single-step event. As such, they also demand political incrementalism. Remember that these steps can be taken in quick succession or over a longer period: what is key is that the character of the third step depends on the success (or otherwise) of the second, the fourth on the third, and so on. In the debates, Ambedkar clearly envisaged that the nature of the political duty being imposed was programmatic. Even on the question of the uniform civil code, he reassured the dissenting minorities by suggesting that it should be pursued in a programmatic manner:

Article 35 ... merely proposes that the State shall endeavour to secure a civil code for the citizens of the country. It does not say that after the Code is framed the State shall enforce it upon all citizens merely because they are citizens ... in the initial stage the application of the Code may be purely voluntary. Parliament may feel the ground by some such method ... ${ }^{135}$

Notice especially the reference to parliament "feeling the ground" with a voluntary code first, and implying it should push ahead only after evaluating its reception. In fact, he may even be implying a duty on the state to constantly evaluate whether the original reasons responsible for the deferral of the directive in the first place continue to obtain. So, if the reason for deferral was resource constraints, the realization duty applies in proportion to available resources, and when that reason is no longer operative, the state's duty to realize the directive becomes fully manifest. On information- sensitive directives concerning the economic organization of the state, Ambedkar was of the view that it was up to each ideological group "to persuade the electorate that it is the best way of reaching economic democracy." 136 So, the test he laid down for making decisions in the context of information scarcity was a democratic one, and therefore reversible when a different ideological party came to power. With respect to deeply divisive directives, there is some suggestion in his advice to "feel the ground" that a mere majoritarian political decision will not do, and that the views of the dissenting minority will be key. In fact, the president of the assembly, Rajendra Prasad, opened the language debate by reminding members "that it will not do to carry a point by debate in this House. The decision of the House should be acceptable to the country as a whole." 137 This was supported by Gadgil, who said of the language directive that the "Hindi people [have to] ... win over the rest by propaganda, not in an aggressive manner but in a persuasive manner." 138 So, directive principles are incrementalist in the constitutional as well as the political sense.

The second feature of their character as deferral tools is that they envisage partial rather than full deferral. To understand the distinction, consider some of the possible questions one could ask in relation to a practical decision:

i. Whether to act on the relevant issue at all?

ii. If yes, what should the action seek to achieve?

134 S. Afr. Const. $\S \S 26(2), 27(2)$, etc.

1357 CAD, Nov. 23, 1948, 551 (Ambedkar) (emphasis added).

1367 CAD, Nov. 19, 1948, 494 (B. R. Ambedkar).

1379 CAD, Nov. 12, 1949, 1312 (emphasis added).

1389 CAD, Sept. 13, 1949, 1371 (N.V. Gadgil). 
iii. Once we know that, how should one go about achieving it?

iv. And finally, when would be a good time to act?

I am not suggesting that most, or even any, administrators actually decide in this way. Lindblom was probably right in suggesting that this means-end separation is not how decision-making actually works in practice. ${ }^{139}$ The suggestion simply is that because the conceptual separation of these stages in decision-making is possible, it is open to a constitution-maker to defer some, but not all, of these questions to a future legislature. A full deferral entails the deferral of all of these questions to the future, whereas a partial deferral settles some of these questions constitutionally but leaves others for politics to sort out later.

Directive principles do not postpone all decisions relating to their subject matter: they are "directives" both in the sense of being directions to the legislature as well as in the sense of being directional, i.e., charting the direction of travel. The when question is clearly deferred; usually so is the how question. On the other hand, subject to the remarks made with reference to the instantiated directives in the previous subsection and political incrementalism in this one, the whether and the what questions are not deferred. As Ananthasayanam Ayyangar told the assembly in relation to rural decentralization, "The only question is about the method and pace with which this object should be achieved." 140 As such, directive principles are tools of partial deferral. This partial deferral is an especial feature of directive principles.

This characterization militates against a more cynical reading of the role that directive principles played in India. Jaffrelot is one of the adherents of such cynicism, who more or less views these principles as a constitutional dustbin for irritating ideas:

Ambedkar accepted an emphatic reference to the village in a section of the Constitution whose articles had no practical implication. In this manner he succeeded in defusing a very strong Gandhian demand that could have questioned the overall framework of his project. In the same manner he sealed the fate of many other Gandhian propositions. ${ }^{141}$

Even though some members in the assembly were similarly cynical about directive principles, ${ }^{142}$ this reading cannot be correct. The three key dissenting groups in the Indian constituent assembly - Gandhians, socialists, and cultural nationalists - did know that they were settling for far less than their ideal solutions. But their representatives were clever people. The ideological battles over directive principles in the assembly would hardly have been as fierce as they were had they thought they were fighting for nothing. Indeed, if Ambedkar himself thought that directive principles "had no practical implication," he would not have bothered to incorporate his own cherished idealsdistributive justice, free primary education, and promotion of the interests of the "lower" castes as directive principles. Incrementalism is not meant to pull the wool over the eyes of dissenters. Because they marked out a zone for legitimate political contest where legal

\footnotetext{
${ }^{139}$ Lindblom, supra note 112.

1407 CAD, Nov. 5, 1948, 429 (M. Ananthasayanam Ayyangar).

141 Jaffrelot, supra note 4, at 112 .

1427 CAD, Nov. 19, 1948, 492 (Hussain Imam): "these principles have been brought in just to silence criticism and to have a good sign-board that we have good intentions, without having any intention of following those directions..."
} 
interference will be minimal, accepting the contested directives wasn't a risk-free strategy for defenders - we will see in the next section that some of these contested directives would be realized in independent India.

\section{Conclusion}

The framers successfully negotiated a constitution that deeply divided groups could sign up to. In part, they did so by accepting some of the transformative agendas of the groups that lost out in the constitutional bargain as expressive directive principles. But these agendas were, first, contained through tools such as dilution, instantiation, and qualification. Second, they were made subject to both constitutional and political incrementalism.

Not everyone was satisfied with the outcome, of course. The very tool of accommodating disagreement through containment and incrementalism was attacked. Lari, a Muslim member, did not like the ambiguity that incrementalist strategies engendered: "It is for the majority to decide one way or the other ... if the House is of the opinion that slaughter of cows should be prohibited, let it be prohibited in clear, definite and unambiguous words. I do not want that there should be a show that you could have this thing although the intention may be otherwise." 143

These calls for sincerity and ideological purity were, however, rare. Most dissenters, like Seth Govind Das, were sufficiently mollified: “... we are not fully satisfied with [only partial recognition of Bharat, cow-protection and Hindi as the national language] ... But the fact that these three things have found place in this Constitution is a matter of gratification." 144

And they had good reasons to be mollified. They were able to hold out hope that there will be another opportunity to battle the issue out at the implementation stage. Advocates were satisfied that the issue would remain on the political agenda. Given the support the defenders had in the assembly, this was the best they could have achieved, short of violent means (which, in turn, would have been very expensive politically). On the other hand, because implementation was likely to be incremental dissenting minorities could frustrate, delay, or negotiate accommodations in attempts to realize the contested directives. Ultimately, all but one member of the assembly signed the final constitutional document.

What also helped was that each of the three populist groups was characteristically optimistic about its political fortunes - if not at the federal level, then at least in the states. Gandhians believed that the vast majority of Indians who lived in the villages would endorse their radical localist agenda. ${ }^{145}$ Socialists could be forgiven for thinking that the mostly poor population would endorse socialism in the polls. Cultural nationalists, with their Hindu-Hindi majoritarian agenda, must have thought that they would have the support of enough voters for victory in a first-past-the-post electoral system. So confident were they that Dhulekar even mocked the cosmopolitan defenders

1437 CAD, Nov. 24, 1948, 577 (Z. H. Lari).

14411 CAD, Nov. 17, 1949, 613 (Seth Govind Das).

14511 CAD, Nov. 17, 1949, 617 (K. Hanumanthaiya): "Though our constitution-makers have not adopted the course of decentralisation, still I have faith in the people of India. They will be able to assert themselves in times to come...." 
in the language debate: "Are they afraid of democracy?"146 That the democratic optimism of each of these groups was going to be complicated, although not entirely frustrated, by the radical diversity of India's electorate would not be discovered until later. At the time of the constitution's framing, India had never been to polls on the basis of universal adult franchise. No one really knew what lay in store for them politically, so the negotiators in the assembly can be said to have been operating behind a kind of Rawlsian veil of ignorance. ${ }^{147}$ This may even suggest that ironically, had the assembly been elected on such franchise, some groups might have been wiser, and possibly more intransigent, if their poor performance had wiped out their democratic optimism before the constitution was adopted. There might even be a general lesson here: that creating constituent assemblies through snapshot direct winner-takes-all elections may actually be a bad thing for democracy. This consideration also suggests a possible qualification to the applicability of the argument of this article to other constitutional contexts: directive principles are likely to be sufficient solace only to those dissenting groups which believe they have the prospects of winning some political power in the putative state (or, at least, in some of its federal units), groups that can hope to draw upon the constitutional directives to support their controversial political agenda.

The details of how these hopes and fears were borne out is a matter for another article. ${ }^{148}$ Briefly, though, the Congress Party would turn even more socialist for a decade or so under Indira Gandhi in the 1970s. Limited rural decentralization would take place in the early 1990s, but accompanied with guaranteed political participation for the lower castes and women in local government. That same period would witness the beginning of the end of state socialism, and economic liberalization would become the dominant state policy. Cultural nationalists would become politically powerful (and even form governments at the federal level) from the late 1990s onward and well into the present. Limited implementation of the directives relating to cow slaughter and alcohol prohibition would happen in several states. Although aspects of religious personal laws would be reformed incrementally, India does not yet have a uniform civil code. Most of the contested directives remain extremely polarizing to this date, and very much on the political agenda. With regard to the uncontested directives, the Congress-led government would put the rudiments of a welfare state in place over a decade starting 2004, finally implementing some of the social directives concerning food security, education, and employment through rights-based legislation. ${ }^{149}$

It seems that the acceptance of directives by the dissenting groups wasn't necessarily, from their partisan viewpoint, a mistake. To put the point differently, dissenters under the DC may not have been losers under the constitution that was ultimately adopted. By carving out a sphere for legitimate politics over their (contained) agendas, the dissenters were given a significant concession. What is clear is that directive principles accommodated divergent, even mutually incompatible, voices within the constitutional

\footnotetext{
1469 CAD, Sept. 13, 1949, 1350 (Dhulekar).

147 John Rawls, A Theory of Justic e 136f (1971). See also Andrew Arato \& Zoltán Miklósi, Constitution Making and Transitional Politics in Hungary, in Framing the State in Times of Transition 350, 375 (Laurel Miller ed., 2010).

${ }^{148}$ Schonthal argues that the incrementalist accommodation of religious divisions in the Sri Lankan Constitution subsequently exacerbated religious conflict in the country. See generally, Benjamin Schonthal, Buddhism, Politics And The Limits Of Law: The Pyrrhic Constitutionalism Of Sri Lanka (2016). However, the opportunity cost of an incrementalist constitutional accommodation in relation to future political conflict is very difficult to determine with certainty.

${ }^{149}$ Sanjay Ruparelia, India's New Rights Agenda: Genesis, Promises, Risks, 18(3) Pac. Aff. 569 (2013).
} 
framework. For this reason, Lakshminarayan Sahu, called the constitution a "mixture," an "unnatural product" that lacked "daring," and predicted that it would last no more than two or three years. ${ }^{150}$ However, its very polyphony ${ }^{151}$ may well have facilitated the surprising - if occasionally wobbly-longevity of India's post-colonial constitution.

${ }^{150} 11$ CAD, Nov. 17, 1949, 613-614 (L. Sahu).

151 Aditya Nigam, A Text Without Author: Locating Constituent Assembly as Event, 39 Econ. \& Pol. Wkly. 2107 (2004). 